\title{
Seroprevalence and predominant serogroups of Leptospira sp. in serological tests of ruminants in northeastern Brazil
}

\section{Soroprevalência e sorogrupos de Leptospira sp. predominantes em exames sorológicos de ruminantes do Nordeste do Brasil}

\author{
Carla Lauise Rodrigues Menezes Pimenta ${ }^{1}$; Camila de Sousa Bezerra ${ }^{1}$; \\ Davidianne de Andrade Morais ${ }^{1}$; Maria Luana Cristiny Rodrigues Silva ${ }^{2}$; \\ Denise Batista Nogueira ${ }^{1}$; Diego Figueiredo da Costa $^{1}$; Carolina de Sousa Américo \\ Batista Santos ${ }^{3}$; Severino Silvano dos Santos Higino ${ }^{3}$; Clebert José Alves ${ }^{3}$; \\ Sérgio Santos de Azevedo ${ }^{3 *}$
}

\begin{abstract}
The objective of this study was to determine the seroprevalence of leptospirosis and the predominant serogroups in serological tests of ruminants performed at the Transmissible Diseases Laboratory of the Federal University of Campina Grande, Patos, Paraíba, northeastern Brazil, between 2010 and 2017. This research included the records of serological tests for leptospirosis from 5594 animals, including 1527 cattle, 1761 goats, 2170 sheep, and 136 buffaloes from four Brazilian states (Paraíba, Pernambuco, Maranhão, and Rio Grande do Norte). Of the 5594 serum samples, 662 were serologically positive, corresponding to a frequency of $11.8 \%$. Serjoe (30.6\%), Autumnalis (13.6\%), and Icterohaemorrhagiae $(11.3 \%)$ were the most frequent subgroups among all species. The individual frequencies in cattle, goats, sheep, and buffaloes were 20\% (306/1527), 8.3\% (147/1761), 7.9\% (171/2170), and 27.9\% (38/136), respectively, with titers ranging from 1:100 to $1: 3200$. The most frequent serogroups according to animal species were as follows: Serjoe predominated in cattle (62\%), followed by Icterohaemorrhagiae $(12.5 \%)$ and Tarassovi (6.6\%); Autumnalis was the most frequent in goats and sheep $(29.4 \%$ and $26.9 \%$, respectively), followed by Seramanga $(12.5 \%)$ in goats and Icterohaemmorrhagiae $(13.5 \%)$ in sheep; and Australis predominated in buffaloes (39.5\%), followed by Pomona (31.6\%) and Canicola $(21.1 \%)$. Leptospira sp. infection, determined by serology, is widespread in ruminants (cattle, goats, sheep, and buffaloes) in northeastern Brazil, suggesting the existence of alternative transmission routes that are less dependent on environmental factors. Identification of the most frequent serogroups highlights the need to improve sanitary conditions, and implement efficient and targeted control measures directed at the primary infection sources.
\end{abstract}

Key words: Leptospirosis. Serology. Ruminants. Serogroups. Control.

\footnotetext{
1 Discentes, Curso de Doutorado, Programa de Pós-Graduação em Medicina Veterinária, Universidade Federal de Campina Grande, UFCG, Patos, PB, Brasil. E-mail: carlalauise@hotmail.com; camilacstr.mv@hotmail.com; davidianneandrademorais@ gmail.com; denise.bn.medvet@gmail.com; diegoveter@hotmail.com

2 Pós-Doutoranda, Programa de Pós-Graduação em Medicina Veterinária, UFCG, Patos, PB, Brasil. E-mail: luacristiny@yahoo. com.br

3 Profs., Programa de Pós-Graduação em Medicina Veterinária, UFCG, Patos, PB, Brasil. E-mail: carolamerico@yahoo.com.br; higinosss@veterinario.med.br; clebertja@uol.com.br; sergio@vps.fmvz.usp.br

* Author for correspondence
} 


\section{Resumo}

O objetivo deste estudo foi determinar a soropositividade para leptospirose e os sorogrupos predominantes nos testes sorológicos realizados no Laboratório de Doenças Transmissíveis (LDT) da Universidade Federal de Campina Grande (UFCG), Patos, Paraíba, Nordeste do Brasil, em bovinos, caprinos, ovinos e bubalinos no período de 2010 a 2017. Foram computados os registros dos exames sorológicos para leptospirose de 5.594 animais, que incluíram 1.527 bovinos, 1.761 caprinos, 2.170 ovinos e 136 bubalinos, provenientes de quatro estados brasileiros (Paraíba, Pernambuco, Maranhão e Rio Grande do Norte). Das 5.594 amostras de soro de bovinos, caprinos, ovinos e bubalinos, 662 amostras foram positivas no teste sorológico, resultando em uma frequência de $11,8 \%$. Serjoe $(30,6 \%)$, Autumnalis $(13,6 \%)$ e Icterohaemorrhagiae $(11,3 \%)$ foram os sorogrupos mais frequentes para todas as espécies. As frequências individuais de bovinos, caprinos, ovinos e bubalinos foram de $20 \%$ (306/1.527), 8,3\% (147/1.761), 7,9\% (171/2.170), e 27,9\% (38/136), respectivamente, com títulos variando de 1:100 a 1:3200. Com relação aos sorogrupos mais frequentes por espécie animal, o Serjoe predominou em bovinos (62\%), seguido de Icterohaemorrhagiae (12,5\%) e Tarassovi $(6,6 \%)$; Autumnalis foi o mais frequente em caprinos e ovinos (29,4\% e $26,9 \%$, respectivamente), seguido de Seramanga $(12,5 \%)$ em caprinos e Icterohaemmorrhagiae (13,5\%) em ovinos; Australis predominou nos bubalinos (39,5\%), seguido de Pomona (31,6\%) e Canicola $(21,1 \%)$. Conclui-se que a infecção por Leptospira sp., determinada por sorologia, encontra-se difundida em ruminantes (bovinos, caprinos, ovinos e bubalinos) do Nordeste do Brasil, o que sugere a existência de vias de transmissão alternativas menos dependentes de fatores ambientais, bem como a identificação dos sorogrupos mais frequentes sugere a necessidade de melhoria das condições sanitárias e implementação de medidas de controle eficientes e direcionadas para as principais fontes de infecção.

Palavras-chave: Leptospirose. Sorologia. Ruminantes. Sorogrupos. Controle.

\section{Introduction}

Leptospirosis is a zoonosis caused by spirochetes of the genus Leptospira, and affects many mammal species including humans. It occurs all over the world, and is particularly prevalent in tropical and subtropical countries, especially in periods of high rainfall rates (AGUIAR et al., 2010; VIEIRA et al., 2018).

In livestock farming, the disease is related to decreases in reproductive performance of the affected herds, resulting to economic losses (ELLIS, 2015). Leptospirosis is transmitted through indirect contact with contaminated water or soil, or through direct contact with the urine of carrier animals (PICARDEAU, 2013). The bacteria enter the host through skin lesions and mucous membranes, invade the circulation, spread throughout the body, and lodge in the renal tubules, being eliminated through urine, thus contaminating the environment and (ADLER, 2014; ELLIS, 2015).
Leptospira infection may be incidental or adapted. The incidental infection, which is highly dependent on environmental factors, is caused by unadapted serogroups transmitted by other domestic or wild animal species. In the latter case, the infection is determined by the adapted serogroups, and is less dependent on environmental conditions, with the maintenance host acting as a natural source of infection for its own species. This infection is associated with specific Leptospira serogroups (FAINE et al., 1999; LEVETT, 2001; SUEPAUL et al., 2011).

The World Organization for Animal Health (OIE) recommends serological diagnosis using the microscopic agglutination test (MAT), particularly for herd diagnosis of production animals (SUEPAUL et al., 2011; PINTO et al., 2015). Thus, seroepidemiological surveys are necessary to monitor and control leptospirosis in a given region. These surveys collect epidemiological indicators that are based on the elaboration of prevention 
strategies and direct new public policies, with the aim of improving general public health.

Several serological studies investigating leptospirosis have been conducted using diagnostic laboratory data. Using data collected in Brazil between 1984 and 1997, a retrospective study by Favero et al. (2002) investigated the prevalent serological variants of leptospirosis in serological tests of sheep, goats, buffaloes, pigs, dogs, and horses from various Brazilian states. Martins and Lilenbaum (2013) evaluated several studies conducted in Rio de Janeiro over a period of 20 years to diagnose leptospirosis in dogs, rats, cattle, horses, goats, sheep, pigs, and wild mammals. Campos et al. (2017) analyzed serum samples from sheep, goats, and cattle from the state of Piauí between 2013 and 2015. In Italy, Tagliabue et al. (2016) epidemiologically evaluated leptospirosis based on serological data from cattle, buffaloes, horse, sheep, goats, pigs, dogs and wild animals from 10 laboratories between 2010 and 2011.

The objective of this study was to determine the frequency of leptospirosis and the prevalent serogroups in serological tests of cattle, goats, sheep, and buffaloes from 2010 to 2017 at the Laboratory of Transmissible Diseases of the Federal University of Campina Grande (UFCG), Patos, Paraíba, Northeast Brazil.

\section{Material and Methods}

\section{Serological diagnosis of Leptospira sp.}

The serological diagnosis of leptospirosis was performed using the MAT assay, according to Galton et al. (1965) and Cole et al. (1973). The tests used a collection of live antigens represented by the serogroups: Icterohaemorrhagiae (serovars Icterohaemorrhagiae and Copenhageni), Canicola, Pomona, Grippotyphosa, Serjoe (Wolff, Hardjoprajitno, Hardjobovis and Guaricura), Australis (Australis and Bratislava), Andamana, Autumnalis (Autumnalis and Butembo), Bataviae,
Balum (Castellonis), Cynopteri, Djasiman (Sentot), Hebdomadis, Panama, Tarassovi, Javanica, Celledoni (Whitcombi), Pyrogenes, Shermani, and Seramanga (Patoc).

The sera were screened at 1:100 dilution, and those exhibiting agglutination $\geq 50 \%$ were titrated by examining a series of two-fold geometric dilutions. Serum titer was the reciprocal of the highest positive dilution. The antigens were examined under a dark-field microscope before being tested for mobility and the presence of selfagglutination or contaminants. To identify the most frequent serogroups, the sera that presented $\geq 2$ serological variants with the highest identical titer were discarded from the serogroup analysis but considered seropositive for Leptospira species (sp.).

\section{Records}

A survey of MAT results to diagnose leptospirosis was used in this study, and the information analyzed was compiled from the database of the Transmissible Disease Laboratory (TDL) of the Federal University of Campina Grande (UFCG), Patos, Paraíba, northeastern Brazil. The records of serological tests for leptospirosis of 5594 animals, including 2170 sheep, 1761 goats, 1527 cattle, and 136 buffaloes from four Brazilian states (Paraíba, Pernambuco, Maranhão, and Rio Grande do Norte) were recorded from 2010 to 2017, and distributed as follows: sheep - PB (94.5\%); PE (5.5\%); goats PB (86.8\%), PE (13.2\%); cattle - PB (53.9\%), MA (20.4\%), RN (15.9\%), PE (9.8\%); and buffaloes PB (100\%).

\section{Results and Discussion}

Of 5594 serum samples from cattle, goats, sheep and buffaloes, 662 were serologically positive, corresponding to a frequency of $11.8 \%$. The most frequent serogroups were identified considering 601 samples. Serjoe $(30.6 \%)$, Autumnalis $(13.6 \%)$, and 
Icterohaemorrhagiae (11.3\%) were the most frequent for all species (Table 1). The frequency of positivity $(11.8 \%)$ can be considered high, which highlights that the infection is broadly spread among the studied species because immunization is not common in most rural properties in northeastern Brazil. Despite the unfavorable environmental conditions for the survival of leptospires in the Brazilian semi-arid region, this high percentage suggests the existence of alternative transmission routes that are dependent on environmental factors. In fact, studies conducted by our research group revealed the possible importance of female-male venereal transmission of leptospirosis in ruminants. Pimenta et al. (2018) investigated a leptospirosis outbreak in cattle in the state of Maranhão and reported that, of 24 cows with reproductive problems (abortion, repeated heat cycles, and stillbirths), eight (33.3\%) tested positive in polymerase chain reaction (PCR) testing using vaginal fluid, with positive genetic sequencing for Leptospira borgpetersenii. Costa et al. (2018) conducted an experimental infection in crossbred Santa Inês sheep, and reported that there was no statistical difference in the proportion of positive urine and vaginal fluid samples using PCR. In another study (SILVA et al., 2018), the DNA of pathogenic leptospires was detected in $54.9 \%$ (61/111) of genital tract samples (uterus, vaginal fluid, and ovary) of sheep slaughtered in Paraíba.

Table 1. Most frequent Leptospira species serogroups from 601 serum samples from cattle, goats, sheep, and buffaloes in northeastern Brazil between 2010 and 2017.

\begin{tabular}{lcc}
\hline Serogroup & Number of positive animals & Frequency (\%) \\
\hline Serjoe & 184 & 30.6 \\
Autumnalis & 82 & 13.6 \\
Icterohaemorrhagiae & 68 & 11.3 \\
Andamana & 43 & 7.2 \\
Australis & 31 & 5.2 \\
Seramanga & 30 & 5.0 \\
Pomona & 27 & 4.5 \\
Djasiman & 25 & 4.2 \\
Tarassovi & 24 & 4.0 \\
Balum & 22 & 3.7 \\
Celledoni & 17 & 2.8 \\
Canicola & 16 & 2.7 \\
Grippotyphosa & 12 & 2.0 \\
Shermani & 8 & 1.3 \\
Javanica & 7 & 1.2 \\
Hebdomadis & 2 & 0.3 \\
Pyrogenes & 1 & 0.2 \\
Cynopeteri & 1 & 0.2 \\
Shermani & 1 & 0.2 \\
\hline
\end{tabular}

The present study revealed the Serjoe serogroup to be the most prevalent in ruminants. This result was expected because this serogroup is most commonly observed in studies involving small ruminants and cattle (MARTINS; LILENBAUM, 2013; DIRECTOR et al., 2014). On the other hand, 
reactions to the Australis and Icterohaemorrhagiae serogroups were related to incidental infections caused by strains found in other domestic and wild animals, suggesting the need to improve sanitary practices, including immunization, antibiotic therapy, environmental management, rodent control and increased environmental hygiene, with the objective of decreasing the spread of leptospirosis (FAINE et al., 1999; ZAKERI et al., 2010).

The positive cattle serotypes in the states of Paraíba, Pernambuco, Maranhão, and Rio Grande do Norte were $6.4 \%, 32.6 \%, 50.9 \%$, and $18.5 \%$, respectively. The positive buffalo serotypes were $27.9 \%$ in the state of Paraíba, while in sheep and goats the frequencies were $7.5 \%$ and $8.5 \%$ for the samples from Paraíba, and $13.4 \%$ and $6.8 \%$ for the samples from Pernambuco, respectively (Table 2). These results reveal a lower number of seropositive small ruminants compared with cattle and buffaloes. This discrepancy can be explained by the rusticity and natural infection resistance attributed to small ruminants (COSTA et al., 2016). On the other hand, Costa et al. (2018) reported greater susceptibility in purebred sheep compared with crossbred animals, emphasizing the importance of the genital tract as a site of extra-urinary infection and the possibility of venereal transmission in sheep.

Table 2. Frequency of positive cattle, goats, sheep and buffaloes in the microscopic agglutination test to diagnose leptospirosis in northeastern Brazil according to state of origin between 2010 and 2017.

\begin{tabular}{lcccc}
\hline State (Brazil) & Species & Number of tested sera & Seropositive samples & Frequency (\%) \\
\hline \multirow{4}{*}{ PB } & Sheep & 2051 & 155 & 7.5 \\
& Goats & 1528 & 131 & 8.5 \\
& Cattle & 822 & 53 & 6.4 \\
& Buffaloes & 136 & 38 & 27.9 \\
PE & Sheep & 119 & 16 & 13.4 \\
& Goats & 233 & 16 & 6.8 \\
MA & Cattle & 150 & 49 & 32.6 \\
RN & Cattle & 312 & 159 & 50.9 \\
\hline
\end{tabular}

The individual frequencies in cattle, goats, sheep, and buffaloes were 20\% (306/1527), 8.3\% (147/1761), 7.9\% (171/2170), and 27.9\% (38/136), respectively, with titers ranging from 1:100 to 1:3200. Among the most frequent serogroups according to animal species (Table 3), Serjoe was predominant in cattle $(62 \%)$, followed by Icterohaemorrhagiae (12.5\%) and Tarassovi (6.6\%); Autumnalis was the most frequent in goats and sheep (29.4\% and 26.9\%, respectively), followed by Seramanga $(12.5 \%)$ in goats and Icterohaemmorrhagiae (13.5\%) in sheep; and Australis predominated in buffaloes (39.5\%), followed by Pomona (31.6\%) and Canicola (21.1\%).
Seropositivity was revealed to be high in cattle, similar to the results reported by Martins and Lilenbaum (2013) in Rio de Janeiro, with a frequency of 23\%; Campos et al. (2017) in Piaú, with 50\%; Pinto et al. (2016) in a systematic review in Latin America, with 44.2\%; Pimenta et al. (2014) in Paraíba, with 61.1\%; and Silva et al. (2012) in Maranhão, with $35.9 \%$. These results are similar to those of the present study, and indicate that the disease, in fact, circulates in the studied cattle herds, emphasizing the impact of this agent on the health of these animals and, consequently, on public health. 
Serjoe was the predominant serogroup in transmission among animals through urine and cattle, being frequently mentioned in several epidemiological surveys in Brazil and in other parts of the world (MARTINS; LILENBAUM, 2013; MENEGAS et al., 2013; PINTO et al., 2015, 2016; TAGLIABUE et al., 2016; CORREIA et al., 2017; CAMPOS et al., 2017). Bovine animals are recognized maintenance hosts of this serogroup, responsible for the development of chronic disease and subclinical persistent reproductive tract infection. Its presence in herds is related to direct vaginal secretions (MARTINS; LILENBAUM, 2013 , 2014). There were also reactions to the Icterohaemorrhagiae and Tarassovi serogroups, which have synanthropic rodents and pigs as maintenance hosts, respectively, suggesting that the presence of rodents plays a fundamental role in environmental contamination (CAMPOS et al., 2017), as well as the contact between cattle and pigs (STRUTZBERG-MINDER; KREIENBROCK, 2011).

Table 3. Prevalence of Leptospira sp. serogroups in cattle, goats, sheep, and buffaloes in northeastern Brazil according to animal species between 2010 and 2017.

\begin{tabular}{lcccc}
\hline \multirow{1}{*}{ Serogroup } & Cattle & Goats & Sheep & Buffaloes \\
\cline { 2 - 5 } & $\begin{array}{c}\text { Number of positive } \\
\text { animals (\%) }\end{array}$ & $\begin{array}{c}\text { Number of positive } \\
\text { animals (\%) }\end{array}$ & $\begin{array}{c}\text { Number of positive } \\
\text { animals (\%) }\end{array}$ & $\begin{array}{c}\text { Number of positive } \\
\text { animals (\%) }\end{array}$ \\
\hline Andamana & $13(4.8)$ & $11(8.1)$ & $19(12.2)$ & $0(0)$ \\
Australis & $6(2.2)$ & $4(2.9)$ & $6(3.8)$ & $15(39.5)$ \\
Autumnalis & $0(0)$ & $40(29.4)$ & $42(26.9)$ & $0(0)$ \\
Balum & $1(0.4)$ & $3(2.2)$ & $18(11.5)$ & $0(0)$ \\
Canicola & $1(0.4)$ & $3(2.2)$ & $4(2.6)$ & $8(21.1)$ \\
Cynopeteri & $0(0)$ & $0(0)$ & $0(0)$ & $1(2.6)$ \\
Grippotyphosa & $8(3.0)$ & $3(2.2)$ & $1(0.6)$ & $0(0)$ \\
Hebdomadis & $2(0.7)$ & $0(0,0)$ & $0(0)$ & $0(0)$ \\
Icterohaemorrhagiae & $34(12.5)$ & $13(9.6)$ & $21(13.5)$ & $0(0)$ \\
Javanica & $0(0)$ & $0(0)$ & $7(4.5)$ & $0(0)$ \\
Seramanga & $7(2.6)$ & $17(12.5)$ & $5(3.2)$ & $1(2.6)$ \\
Pomona & $7(2.6)$ & $3(2.2)$ & $0(0)$ & $12(31.6)$ \\
Pyrogenes & $0(0)$ & $1(0.7)$ & $12(7.7)$ & $0(0)$ \\
Djasiman & $2(0.7)$ & $11(8.1)$ & $9(5.8)$ & $0(0)$ \\
Serjoe & $168(62)$ & $5(3.7)$ & $3(1.9)$ & $1(2.6)$ \\
Shermani & $3(1.1)$ & $3(2.2)$ & $1(0.6)$ & $0(0)$ \\
Tarassovi & $18(6.6)$ & $5(3.7)$ & $3(1.9)$ & $0(0)$ \\
Celledoni & $0(0)$ & $14(10.3)$ & $156(100)$ & $0(0)$ \\
Total & $270(100)$ & $136(100)$ & & $38(100)$ \\
\hline & & & & \\
\hline
\end{tabular}

The frequencies for goats and sheep were 8.3\% and $7.9 \%$, respectively. Studies conducted by Tagliabue et al. (2016) in Italy, and Suwancharoen et al. (2013) in Thailand, reported frequencies similar to the present study $(4.7 \%$ for sheep and $7.9 \%$ for goats), while other authors reported higher results in the same species, such as Aguiar et al. (2010), who reported $33.3 \%$ positivity in sheep in Rondônia; Salaberry et al. (2011), who reported 22.2\% positivity in sheep in Minas Gerais; Martins and Lilenbaum (2013), who reported $47.4 \%$ positivity in sheep and $14.95 \%$ in goats in 
Rio de Janeiro; Cortizo et al. (2015), who reported $50 \%$ positivity in both species in Espírito Santo; and Machado et al. (2016), who reported 19.5\% positivity in sheep in Pernambuco. The discrepancy among results is probably due to the characteristic environmental conditions of each region studied, and the management and control measures adopted for the herds (COSTA et al., 2016; MACHADO et al., 2016).

The Autumnalis serogroup was the most frequent in goats and sheep, a result that corroborates the findings of serological surveys conducted in Paraíba, Minas Gerais and Pernambuco in previous years (HIGINO et al., 2010; ALVES et al., 2012; SALABERRY et al., 2011; COSTA et al., 2016; MACHADO et al., 2016), suggesting that this serogroup may be adapted to small ruminants. The serogroup Seramanga was the second most frequent in goats. It is considered non-pathogenic and associated with the presence of rodents and free-living animals in properties, such as whiteeared opossums (Didelphis albiventris), acting as sources of infection (SILVA et al., 2013; PAIXÃO et al., 2016). The Icterohaemorrhagiae is considered the second most frequent serogroup in sheep and is generally related to the presence of rodents, responsible for incidental infections in other hosts (ESCÓCIO et al., 2010; GENOVEZ et al., 2011).

In buffaloes, the seropositivity was $27.9 \%$, a result lower than reported by Viana et al. (2009) and Favero et al. (2002), who evaluated buffaloes in Amazonas and São Paulo and reported frequencies of $80 \%$ and $43.7 \%$, respectively. Although these frequencies are considered to be high, they were lower than in other studies, probably because the state of Paraíba is located in a semi-arid region of Brazil and, consequently, presents adverse climatic conditions for leptospirosis, which results in low seropositivity.

The Australis serogroup was the most frequent in buffaloes, as observed by Viana et al. (2009), who evaluated buffaloes from the state of
Amazonas, although most serological surveys indicate the Serjoe serogroup as the most prevalent (FAVERO et al., 2002; SUWANCHAROEN et al., 2013; TAGLIABUE et al., 2016). The serogroups Pomona and Canicola were the second and third most frequent, respectively. The high pathogenicity attributed to the Pomona serogroup suggests that buffalo herds have an active immune response against leptospirosis (PAIXÃO et al., 2016), and pigs may be acting as reservoirs for both the Australis and Pomona serogroups because these animals are recognized hosts of these serogroups. Their presence in properties is strongly associated with the occurrence of incidental leptospirosis (LILENBAUM; SOUZA, 2003). As for the Canicola serogroup, the close contact between buffaloes and dogs may justify the identification of this serogroup as one of the most frequent in buffaloes, given that dogs are considered adapted and serve as leptospirosis reservoirs (MARTINS; LILENBAUM, 2013).

\section{Conclusion}

Serologically diagnosed Leptospira sp. infection is widespread in ruminants (i.e., cattle, goats, sheep, and buffaloes) in northeastern Brazil, suggesting the existence of alternative transmission routes that are less dependent on environmental factors. The identification of the most frequent serogroups enables us to infer that these bacteria are maintained in cattle herds through direct contact among animals, while in herds of other species, the bacteria are maintained through contact with other domestic and synanthropic animals, which highlights the need to improve sanitary conditions, and implement efficient and targeted control measures directed at the primary infection sources.

\section{References}

ADLER, B. Pathogenesis of leptospirosis: cellular and molecular aspects. Veterinary Microbiology, Amsterdam, v. 172 , n. $3-4$, p. $353-461,2014$. DOI: $10.1016 /$ j. 
vetmic.2014.06.015

AGUIAR, D. M.; CAVALCANTE, G. T.; VASCONCELLOS, S. A.; SOUZA, G. O.; LABRUNA, M. B.; CAMARGO, L. M. A.; GENNARI, S. M. Anticorpos anti-Leptospira spp. em ovinos do município de Monte Negro, estado de Rondônia. Arquivos do Instituto Biológico, São Paulo, v. 77, n. 3, p. 529-532, 2010 .

ALVES, C. J.; ALCINDO, J. F.; FARIAS, A. E. M.; HIGINO, S. S. S.; SANTOS, F. A.; ZEVEDO, S. S.; COSTA, D. F.; SANTOS, C. S. A. B. Caracterização epidemiológica e fatores de risco associados à leptospirose em ovinos deslanados do semiárido brasileiro. Pesquisa Veterinária Brasileira, Rio de Janeiro, v. 32, n. 6, p. 523$528,2012$.

CAMPOS, A. P.; MIRANDA, D. F. H.; RODRIGUES, H. W. S.; LUSTOSA, M. S. C MARTINS, G. H. C.; MINEIRO, A. L. B.; CASTRO, V.; AZEVEDO, S. S.; SILVA, S. M. M. S. Seroprevalence and risk factors for leptospirosis in cattle, sheep, and goats at consorted rearing from the State of Piauí, northeastern Brazil. Tropical Animal Health and Production, Edinburgh, v. 49, n. 5, p. 899-907, 2017. DOI: $10.1007 /$ s11250-0171255-2

COLE, J. R.; SUlZER, C. R.; PULSSELY, P. R. Improved microtechnique for the leptospiral microscopic aglutination. Applied Microbiology, Washington, v. 5, n. 6, p. 976-980, 1973.

CORREIA, L.; LOUREIRO, A. P.; LILENBAUM, W. Effects of rainfall on incidental and host-maintained leptospiral infections in cattle in a tropical region. The Veterinary Journal, New York, v. 220, n. 1, p. 63-64, 2017. DOI: 10.1016/j.tvj1.2016.12.016

CORTIZO, P.; LOUREIRO, A. P.; MARTINS, G.; RODRIGUES, P. R.; FARIA, B. P.; LILENBAUM, W.; DEMINICIS, B. B. Risk factors to incidental leptospirosis and its role on the reproduction of ewes and goats of Espírito Santo state, Brazil. Tropical Animal Health and Production, Edinburgh, v. 47, n. 1, p. 231235, 2015. DOI: 10.1007/s11250-014-0684-4

COSTA, D. F.; SILVA, A. F.; FARIAS, A. E. M.; BRASIL, A. W. L.; SANTOS, F. A.; GUILHERME, R. F. G.; AZEVEDO, S. S.; ALVES, C. J. Serological study of the Leptospira spp. infection in sheep and goats slaughtered in the State of Paraíba, semiarid of Northeastern Brazil. Semina: Ciências Agrárias, Londrina, v. 37, n. 2, p. 819828, 2016. DOI: 10.5433/1679-0359.2016v37n2p819

COSTA, D. F.; SILVA, M. L. C. R.; MARTINS, G.; DANTAS, A. F. M.; MELO, M. A.; AZEVEDO, S. S.; LILENBAUM, W.; ALVES, C. J. Susceptibility among breeds of sheep experimentally infected with Leptospira interrogans Pomona serogroup. Microbial Pathogenesis, Amsterdam, v. 122, n. 1, p. 79-83, 2018. DOI: 10.1016/j. micpath.2018.06.017

DIRECTOR, A.; PENNA, B.; HAMOND, C.; LOUREIRO, A. P.; MARTINS, G.; MEDEIROS, M. A.; LILENBAUM, W. Isolation of Leptospira interrogans Hardjoprajitno from vaginal fluid of a clinically healthy ewe suggests potential for venereal transmission. Journal of Medical Microbiology, Edinburgh, v. 63, n. 9, p. 12341236, 2014. DOI: 10.1099/jmm.0.065466-0

ELLIS, W. A. Animal leptospirosis. Current Topics in Microbiology and Immunology, Tokyo, v. 387, n. 1, p. 99-137, 2015.

ESCÓCIO, C.; GENOVEZ, M. E.; CASTRO, V.; PIATTI, R. M.; GABRIEL, F. H. L.; CHIEBAO, D. P.; AZEVEDO, S. S.; VIEIRA, S. R.; CHIBA, M. Influência das condições ambientais na transmissão da leptospirose entre criações de ovinos e bovinos da região de Sorocaba, SP. Arquivos do Instituto Biológico, São Paulo, n. 77, v. 3, p. 371-379, 2010.

FAINE, S.; ADLER, B.; BOLIN, C.; PEROLAT, P. Leptospira and Leptospirosis. $2^{\text {th }}$ ed. Melbourne: MediSci Press, 1999. 272 p.

FAVERO,A. C. M.; PINHEIRO, S. R.; VASCONCELOS, S. A.; MORAIS, Z. M.; FERREIRA, F.; FERREIRA NETO, J. S. Sorovares de leptospira predominantes em exames sorológicos de bubalinos, ovinos, caprinos, equinos, suínos e cães de diversos estados brasileiros. Ciência Rural, Santa Maria, v. 32, n. 4, p. 613-619, 2002.

GALTON, M. M.; SULZER, C. R.; SANTA ROSA, C. A.; FIELDS, M. J. Application of a microtechnique to the agglutination test for leptospiral antibodies. Applied Microbiology, Washington, v. 13, n. 1, p. 81-85, 1965.

GENOVEZ, M. E.; ESCÓCIO, C.; CASTRO, V.; GABRIEL, F. H. L.; CHIEBAO, D. P.; AZEVEDO, S. S., 2011. Fatores de risco associados à infecção pela Leptospira spp. sorovar hardjo em rebanhos exclusivos de ovinos e nos consorciados com bovinos. Arquivos do Instituto Biológico, São Paulo, v. 78, n. 4, p. 587-592, 2011.

HIGINO, S. S. S.; AZEVEDO, S. S.; ALVES, C. J.; FIGUEIREDO, S. M.; SILVA, M. L. C. R.; BATISTA, C. S. A. Frequência de leptospirose em ovinos abatidos no município de Patos, Paraíba. Arquivos do Instituto Biológico, São Paulo, v. 77, n. 3, p. 525-527, 2010.

LEVETT, P. N. Leptospirosis. Clinical Microbiology Reviews, Washington, v. 14, n. 2, p. 296-326, 2001.

LILENBAUM, W.; SOUZA, G. N. Factors associated with bovine leptospirosis in Rio de Janeiro, Brazil. 
Research in Veterinary Science, London, v. 75, n. 3, p. 249-251, 2003. DOI: 10.1016/S0034-5288(03)00114-0

MACHADO, A. C.; OLIVEIRA, J. M. B.; SILVA JÚNIOR, J. L.; ASSIS, N. A.; BRANDESPIM, D. F.; MATHIAS, L. A.; MOTA, R. A.; PINHEIRO JÚNIOR, J. W. Epidemiologic analysis of Leptospira spp. infection among sheep in Pernambuco state, Brazil. Arquivos do Instituto Biológico, São Paulo, v. 83, n. 1, p. 1-7, 2016. DOI: $10.1590 / 1808-1657000222014$

MARTINS, G.; LILENBAUM, W. Leptospirosis in cattle: a challenging scenario for the understanding of the epidemiology. Transboundary and Emerging Diseases, New York, v. 61, n. 1, p. 63-71, 2014. DOI: ttps://doi. org/10.1111/tbed.12233

MARTINS, G.; LILENBAUM, W. The panorama of animal leptospirosis in Rio de Janeiro, Brazil, regarding the seroepidemiology of the infection in tropical regions. $B M C$ Veterinary Research, Paris, v. 9, n. 237, p. 1-7, 2013. DOI: $10.1186 / 1746-6148-9-237$

MENEGAS, P. H.; TONETTE, G.; OLIVEIRA, L. A.; FREITAS, J. C.; GONÇALVES, D. D. Leptospirose em propriedade rural com histórico de aborto bovino da região centro-sul do estado do paraná - relato de caso. Enciclopédia Biosfera, Jandaia, v. 9, n. 17, p. 1783-1792, 2013.

PAIXÃO, A. P.; SANTOS, H. P.; ALVES, L. M. C.; PEREIRA, H. M.; CARVALHO, R. F. B.; COSTA FILHO, V. M.; OLIVEIRA, E. A. A.; SOARES, D. M.; BESERRA, P. A. Leptospira spp. em bovinos leiteiros do estado do Maranhão, Brasil: frequência, fatores de risco e mapeamento de rebanhos reagentes. Arquivos do Instituto Biológico, São Paulo, v. 83, n. 1, p. 1-12, 2016.

PICARDEAU, M. Diagnosis and epidemiology of leptospirosis. Médicine et Maladies Infectieuses, Paris, $\mathrm{n}$. 43,n. 1,p. 1-9,2013.DOI: 10.1016/j.medmal.2012.11.005

PIMENTA, C. L. R. M.; CASTRO, V.; CLEMENTINO, I. J.; ALVES. C. J.; FERNANDES, L. G.; BRASIL, A. W. L.; SANTOS, C. A. S. B.; AZEVEDO, S. S. Leptospirose bovina no Estado da Paraíba: prevalência e fatores de risco associados à ocorrência de propriedades positivas. Pesquisa Veterinária Brasileira, Rio de Janeiro, v. 34, n. 4, p. 332-336, 2014. DOI: 10.1590/ S0100-736X2014000400005

PIMENTA, C.L.R. M.; COSTA, D. F.; SILVA, M. L. C.R.; PEREIRA, H. D.; ARAÚJO JÚNIOR, J. P.; MALOSSI, C. D.; ULLMAN, L. S.; ALVES, C. J.; AZEVEDO, S. S. Strategies of the control of an outbreak of leptospiral infection in dairy cattle in Northeastern Brazil. Tropical Animal Health and Production, Edinburgh, v. 51, n. 1, p. 237-241, 2018. DOI: /10.1007/s11250-018-1635-2
PINTO, P. S.; LIBONATI, H.; PENNA, B.; LILENBAUM, $\mathrm{W}$. A systematic review on the microscopic agglutination test seroepidemiology of bovine leptospirosis in Latin America. Tropical Animal Health and Production, Edinburgh, v. 48, n. 2, p. 239-248, 2016. DOI: $10.1007 /$ s11250-018-1635-2

PINTO, P. S.; LOUREIRO, A. P.; PENNA, B.; LILENBAUM, W. Usage of Leptospira spp. local strains as antigens increases the sensitivity of the serodiagnosis of bovine leptospirosis. Acta Tropica, Basel, v. 149, n. 1, p. 163-167, 2015. DOI: 10.1016/j.actatropica.2015.05.008

SALABERRY, S. R. S.; CASTRO, V.; NASSAR, A. F. C.; CASTRO, J. R.; GUIMARAES, E. C.; LIMA-RIBEIRO, M. C. Seroprevalence and risk factors of antibodies against Leptospira spp. In ovines from Uberlândia municipality, Minas Gerais State, Brazil. Brazilian Journal of Microbiology, São Paulo, v. 42, n. 4, p. 14271433, 2011. DOI: 10.1590/S1517-83822011000400026

SILVA, A. F.; FARIAS, P. J. A.; SILVA, M. L. C. R.; ARAÚJO JÚNIOR, J. P.; MALOSSI, C. D.; ULLMANN, L. S.; COSTA, D. F.; HIGINO, S. S. S.; AZEVEDO, S. S.; ALVES, C. J. High frequency of genital carriers of Leptospira sp. in sheep slaughtered in the semi-arid region of Northeastern Brazil. Tropical Animal Health and Production, Edinburgh, v. 51, n. 1, p. 43-47, 2019. DOI: $10.1007 / \mathrm{s} 11250-018-1657-9$

SILVA, F. J.; CONCEIÇÃO, W. L. F.; FAGLIARI, J. J.; GIRIO, R. J. S.; DIAS, R. A.; BORBA, M. R. B.; MATHIAS, L. A. Prevalence and risk factors of bovine leptospirosis in the State of Maranhão, Brazil. Pesquisa Veterinária Brasileira, Rio de Janeiro, v. 32, n. 4, p. 303312, 2012. DOI: 10.1590/S0100-736X2012000400006

SILVA, F. J.; SILVA, T. R.; SILVA, G. C. P.; SANTOS, C. E. P.; ALVES JUNIOR, J. R. F.; MATHIAS, L. A. Isolation of Leptospira borgpetersenii in synanthropic Didelphis albiventris in Jaboticabal, São Paulo, Brazil. Brazilian Journal of Veterinary Research and Animal Science, São Paulo, v. 50, n. 6, p. 457-461, 2013. DOI: 10.11606/issn.1678-4456.v50i6p457-461

STRUTZBERG-MINDER, K. S.; KREIENBROCK, L. Leptospireninfektionen beim schwein: epidemiologie, diagnostik und weltweites vorkommen. Berliner und Münchener Tierärztliche Wochenschrift, Berlin, v. 124, n. 9-10, p. 345-359, 2011. DOI: 10.2376/0005-9366-124345

SUEPAUL, S. M.; CARRINGTON, C. V.; CAMPBELL, M.; BORDE, G.; ADESIYUN, A. A. Seroepidemiology of leptospirosis in livestock in Trinidad. Tropical Animal Health and Production, Edinburgh, v. 43, n. 2, p. 367375, 2011. DOI: $10.1007 / \mathrm{s} 11250-010-9698-8$ 
SUWANCHAROEN, D.; CHAISAKDANUGULL, Y.; HANAPONGTHARM, W.; YOSHIDA, S. Serological survey of leptospirosis in livestock in Thailand. Epidemiology and Infection, Cambridge, v. 141, n. 11, p. $2269-2277,2013$. DOI: $10.1017 / \mathrm{S} 0950268812002981$

TAGLiABUE, S.; FIGAROLli, B. M.; D'INCAU, M.; FOSCHI, G.; GENNERO, M. S.; GIORDANI, R.; GIORDANI, R.; NATALE, A.; PAPA, P.; PONTI, N.; SCALTRITO, D.; SPADARI, L.; VESCO, G.; UOCCO, L. Serological surveillance of Leptospirosis in Italy: twoyear national data (2010-2011). Veterinaria Italiana, Teramo, v. 52, n. 2, p. 129-138, 2016.

VIANA, R. B.; DEL FAVA, C.; MOURA, A. C. B.; CARDOSO, E. C.; ARAÚJO, C. V. de; MONTEIRO, B. M.; PITUCO, E. M.; VASCONCELLOS, S. A. Ocorrência de anticorpos anti-Neospora caninum, Brucella sp.e Leptospira spp. em búfalos (Bubalus bubalis) criados na Amazônia. Arquivos do Instituto Biológico, São Paulo, v. 76, n. 3, p. 453-457, 2009.

VIEIRA, A. S.; PINTO, P. S.; LILENBAUM, W. A systematic review of leptospirosis on wild animals in Latin America. Tropical Animal Health and Production, Edinburgh, v. 50, n. 2, p. 229-238, 2018. DOI: $10.1007 /$ s11250-017-1429-

ZAKERI, S.; KHORAMI, N.; GANJI, Z. F.; SEPAHIAN, N.; MALMASI, A.; GOUYA, M. M.; DJADID, N. D. Leptospira wolffii,apotential new pathogenic Leptospira species detected in human, sheep and dog. Infection, Genetics and Evolution, Amsterdam, v. 10, n. 2, p. 273277, 2010. DOI: 10.1016/j.meegid.2010.01.001 